\title{
Cooperative Learning as a Preference of Adolescent Students: The Case of Dance Activities
}

\author{
Darginidou Lemonia \\ Goulimaris Dimitris \\ Department of Physical Education and Sport Science, \\ Democritus University of Thrace, Greece \\ Email: Idargini@phyed.duth.gr
}

\section{Doi:10.5901/ajis.2016.v5n3s1p478}

\section{Abstract}

\begin{abstract}
There are a number of extracurricular activities, carried out in today junior high schools, which give priority to the interaction between individuals and groups. Dance-as an extracurricular, physical activity with educational characteristics and cooperative elements - is believed to develop social and cultural values, since it creates emotional bonds between the individual and the group. The fact that a learning method is preferred by students can influence their performance. The aim of the study is to investigate students' preferences concerning cooperative or individual learning methods and the difficulties of group work. The sample of the study was made up of 289 students, at the age of 13. Three groups were created. The first group was constituted of adolescents who took up extracurricular dance activities organized by the state. The second group was constituted of adolescents participating in extracurricular dance activities organized by non profit private societies. The third group was made up of adolescents who did not take up any physical activity in their free time. The Greek version (Goudas, Magotsiou, \& Hatzigeorgiadis, 2009) of the "Feelings towards Group Work Scale» (Cantwell \& Andrews, 2002) was used. The results showed differences among all groups. The adolescents involving in private dance activity programs presented a higher preference in group learning methods than adolescents involving in state dance activity programs. This is probably due to the higher efficiency of the teachers working in the private sector. The group that did not involve in any extracurricular activity preferred the individual work method.
\end{abstract}

Keywords: cooperative learning, dance activities, adolescent students

\section{Introduction}

There are a number of learning strategies adopted in today schools, which are based on modern international tendencies, theoretical pedagogic approaches and school psychology attitudes (Fagan \&Wise, 2000; Oakland \& Jimerson, 2007; Frisby \& Jimerson, 2016). Performance is improved and qualitative characteristics, supportive to knowledge appear, through interaction and communication among groups of students (Joyce \& Weil, 1992; Sharan \& Shachar, 1988; Slavin, 1989; Cohen, 1994).

Cooperative learning or group work method is a form of learning which assumes a common effort in order to achieve a common target (Dyson, 2002). During cooperative learning, the participants work in miscellaneous groups with internal encouragement and support. The group members use their social skills so as to develop cooperation, through responsibility and positive attitude, aiming at both the personal and group learning, while simultaneously there is an evaluation of the group progress (Johnson \& Johnson, 1989). Some characteristics of cooperative learning are cooperative skills, interdependence and personal responsibility. Since preferring cooperative learning can influence students' performance, it is important that there is a method to evaluate students' attitude and way of work.

Students' learning preferences refer to their choices in relation to the structure of the class they prefer to work with. These choices concentrate on whether students prefer a) to cooperate with their fellow students while completing educational units and work material (cooperative structure) which means that they learn better what they have to learn $b$ ) to compete among them while achieving any results (competitive structure) c) to work individually, without mingling with their peers, following their own academic targets (individual structure).

In Greek schools there are a lot of group/cooperative programs of extracurricular school activities, which give priority to the interaction between individual and group. These programs mainly divide work into groups, resulting at the improvement of students in all fields. They also require and aim at developing the students' social skills. In physical 
education, cooperative learning leads the students to more creative activities, with higher possibilities of success (Barker, Quennerstedt, \& Annerstedt, 2015; Casey \& Dyson, 2012). In the frame of Physical Education, there is an increasing interest in cooperative rather than competitive learning structure, as educational approach (Brown \& Grineski, 1992; Greendorfer, 1987; Casey \& Dyson, 2012; Ensergueix \& Lafont, 2010; Goodyear, Casey, \& Kirk,2012).

In 2003, Danish et al highlighted that sport activities can help transport athletic skills to every day life. Greek dance is a kind of physical activity (Pitsi, Tokmakidis, Serbezis \& Goulimaris, 2008) for all ages, which creates an emotional connection among the members of the group (McNeill, 1995). As a physical activity, with educational characteristics and cooperative elements, it is believed to develop social, cooperative and cultural values. In addition, Greek dance is a part of school physical education and is indicative for interaction and development of social skills (Lobo \& Winsler, 2006).

The investigation of the students' preferences concerning work and learning processes during school activity programs is scarce in Greece. This is also true, as far as dance lessons are concerned. This lack of investigation has initiated this study.

So, the aim of the study is to investigate the students' preferences in relation to cooperative or individual learning methods as well as the difficulties of cooperative work. The authors carry out a comparison among three groups of students; the first group takes part in extra curricular dance activities organized by the state. The second group participates in similar activities organized by non profit private societies and the third group does not take part in any physical activity.

\section{Methodology}

\subsection{Participants}

The sample of the research consisted of 289 adolescent students, aged 13. Three groups were created. The $1^{\text {st }}$ group was made up of 91 adolescents, who participated in extra curricular school dance programs organized by the state (Greek dances). The $2^{\text {nd }}$ group was made up of 94 adolescents who participated in dance activities (Greek dances) organized by non profit private societies. The $3^{\text {rd }}$ group was made up of 104 adolescents, who did not participate in any physical activity in their free time.

\subsection{Measurement instruments}

To evaluate the students' preference concerning a work method, the instrument used was the "Feelings Towards Group Work (FTGW)" (Cantwell \& Andrews 2002), adjusted for the Greek language by Goudas, Magotsiou \& Hatzigeorgiadis in 2009. The scale evaluates the attitude and perception of students towards group work and has been used for researches in Greece (Gousia \& Kouthouris, 2011; Filippou \& Kouthouris, 2014). It consists of 24 issues, categorized in three subscales. 1) The first subscale is "Preference of group learning". It has 8 issues e.g. "I like working in a group because in this way we help each other". 2) The second subscale is "Preference for individual group work". It has 9 issues e.g. "I prefer working individually, because in this way I am in a better mood for learning". 3) The third subscale is "Feeling of discomfort in groups". It has 7 issues e.g. "I often feel suffocating and I want to quit working in a group". The answers were given in a five degree Likert type scale (from 1=I totally disagree, $2=\mid$ disagree, $3=\mid$ am not certain, to $5=1$ totally agree).

\subsection{Procedure}

The meetings with the students took place in the environment where the dance activities were carried out i.e. outside school or in one of the societies. There was a brief time period for instructions and questions before filling in the questionnaires, which had to be returned before the end of the meetings.

\subsection{Statistical analysis}

To examine the differences among the three groups concerning work method preferences (group work, individual work, group work difficulties) one way analysis of variance (one way ANOVA) was used. There followed post hoc test, in order to check the differences among the groups. 


\section{Results}

Table 1 presents the means and standard deviations of the subscales concerning work preferences among the three groups.

Table 1. Means and standard deviations of the groups concerning work preferences.

\begin{tabular}{lcccccccc} 
& \multicolumn{9}{c}{ Groups } & \multicolumn{2}{c}{ 3rd $^{\text {1st }}$} & \multicolumn{2}{c}{ Total } \\
\hline Subscales & $\mathrm{M}$ & S.D. & $\mathrm{M}$ & S.D. & $\mathrm{M}$ & S.D. & M & S.D. \\
\hline Group learning & 4.30 & 0.35 & 4.66 & 0.24 & 4.00 & 0.65 & 4.31 & 0.53 \\
Individual group work & 2.23 & 0.53 & 2.16 & 0.28 & 2.68 & 0.63 & 2.37 & 0.56 \\
Feeling of discomfort in groups & 1.45 & 0.37 & 1.21 & 0.27 & 1.86 & 0.84 & 1.52 & 0.63 \\
\hline
\end{tabular}

One way ANOVA shows that there are statistically significant differences in group work $F(2,286)=51.9, p<0.05$, in individual work $\left.F_{(2,286)}=31.2, p<0.05\right)$ and in group work difficulties $F_{(2.286)}=33.8, p<0.05$. The post hoc test Scheffe shows that: a) In the subscale "Preference of group learning" the $2^{\text {nd }}$ group has a higher means $(M=4.66, S D=0.24)$ than the $1^{\text {st }}$ group $(M=4.29, S D=0.35)$ and the $3^{\text {rd }}$ group $(M=4.00, S D=0.65)$. $\left.b\right)$ In the subscale "Preference for individual group work" the $3^{\text {rd }}$ group has a higher means $(M=2.68, S D=0.63)$ than the $1^{\text {st }}$ group $(M=2.23, S D=0.53)$ and the $2^{\text {nd }}$ group $(M=2.16, S D 0.28) . c)$ In the subscale "Feeling of discomfort in groups" the $3^{\text {rd }}$ group has a higher means $(M=1.86$, $\mathrm{SD}=0.84)$ than the $1^{\text {st }}$ group $(M=1.45, S D=0.37)$ and the $2^{\text {nd }}$ group $(M=1.21, S D=0.27)$.

\section{Discussion}

The aim of the research was to investigate students' preferences concerning group or individual work learning methods and the perceivable difficulties of group work. There was a comparison among the preferences of the student groups, which participated in extra curricular dance activities outside school, in dance activities in non profit private societies or did not participate in any athletic activity.

The results showed that there are differences in all three groups.

The students who belonged in the group that took up dance activities in non profit private societies, preferred group work, showing a preference for the composition and dynamics of their group and displaying a sense of self knowledge, comfort and responsibility as concerns their position in the group. This group had the higher means of preference concerning group work learning methods, in relation to the group that took up extra curricular school activity programs organized by the state. This is probably due to the better specialization and larger experience of the teachers who do not work for the state or it is the result of a different organizing culture between school and non profitable societies. In dance activities, interaction and cooperation among the participants is direct and inevitable. There is a certain behaviour which focuses on "us", meaning a sense of "belonging together" (McMillan \& Chavis, 1986; Sarason, 1974). The concept of the group is an ingredient which is transferred through dance activities to every day life (Bougiesi, Zisi, Grigoriou \& Pollatou, 2011).

On the contrary, the students who do not take up physical activities in their free time prefer the individual way of work. It seems that they have a lower appreciation of the structural nature of group work, which is due to low self esteem and reluctance to take the necessary responsibilities when participating in a group. They find it difficult to adapt and embody in a group, they show emotions of insecurity, they fear a possible alienation and rejection from the group and they have difficulties in communicating, which means that they have reduced social skills.

\section{Conclusions}

The research revealed that group work learning methods are highly preferred by students who deal with dance activities in non profit private societies, followed by students who take up extra curricular dance activity programs in school. As for students who are not involved in any physical activity in their free time, they prefer individual work, having group work difficulties. These results are important, as they are supportive of researches concerning the development of sociability and social skills of students who are involved in dance activities. The identification and classification of the students' perceptions and emotions contribute to the improvement of adopting learning methods in groups and to the positive results of intervention programs, which aim at ameliorating the cooperative skills of students (Merrel, 2001). Thus, it is highly suggested that similar researches should be carried out, including more adolescent ages. 


\section{References}

Barker, D., Quennerstedt, M. \& Annerstedt, C. (2015). Learning through group work in physical education: a symbolic interactionist approach. Journal of Sport, Education and Society,20(5).

Brown, L., \& Grineski, S. (1992). Competition in physical education: an educational contradiction? Journal of Physical Education, Recreation and Dance, 63 (1), 17-19, 77.

Bougiesi, M., Zisi, B., Gregory, S. \& Pollatou, E. (2011). Greek Folk Dance Systematic Participation Affects Quality of Life in Young and Middle Age (in Greek). Inquiries in sport \& Physical Education, 9 (2),134-143.

Cantwell, R. H., \& Andrews, B. (2002). Cognitive and psychological factors underlying secondary school students' feelings towards group work. Educational Psychology, 22, 75-91.

Casey, A., \& Dyson, B. (2012). Cooperative learning in physical education. In B. Dyson \&A. Casey (Eds.), Cooperative learning in physical education: A research-based approach (pp. 166-175). London: Routledge.

Cohen, J. (1994). The earth is round ( $p<.05)$. American Psychologist, 49, 997-1003.

Danish, S.J., Hodge, K., Hake, I., \&Taylor, T., (2003). Sport and childhood: Promoting healthy development of youth truth physical activity and sport. In T. Gulot \& Bloom (eds).

Dyson, B. (2002). The implementation of cooperative learning in an elementary Physical Education program. Journal of Teaching in Physical Education, 22, 69-85.

Ensergueix, P. J., \& Lafont, L. (2010).Reciprocal peer tutoring in a physical education setting: Influence of peer tutor training and gender on motor performance and self-efficacy outcomes. European Journal of Psychology of Education, 25, 222242.doi:10.1007/s10212-009-0010-0

Fagan, T., \& Wise, P.S. (2000). School psychology: Past, present, and future (2nd ed.). Bethesda, MD: National Association of School Psychologists.

Filippou, K. \& Kouthouris, C. (2014). The Role of the Camping Participation for the Development of Social Skills. Investigating Differences between Typical Camps and Camps with Outdoor Activity Programs( in Greek). Hellenic Journal of Sport \& Recreation Management. 11 (1), 55-72

Frisby, C. L. \& Jimerson, S. R. (2016). Understanding immigrants, schooling, and school psychology: Contemporary science and practice. School Psychology Quarterly, 31(2), 141-148.

Goudas, M., Magotsiou, E. \& Hatzigeorgiadis, A. (2009). Psychometric properties of the Greek version of the Feelings Toward Group Work Questionnaire. European Journal of Psychological Asessment, 25: 204-210.

Goodyear, V. A., Casey, A., \& Kirk, D. (2012).Hiding behind the camera: social learning within the Cooperative Learning Model to engage girls in physical education. Sport, Education and Society, 19, 712-734.

Gousia,V. \& Kouthouris,C. (2011).Investigating Team Work Perceptions of Elementary school student's after Participation in an Outdoor Education Program. (in Greek) Greek Society of Sport Management 8 (2), 18 - 28.

Greendorfer, S. I. (1987). Psychosocial correlates of organized physical activity. Journal of Physical Education, Recreation and Dance, 58 (7), 59-64.

Johnson, D.W., \& Johnson, R. (1989a). Cooperation and competition: Theory and Research. Edina, MN: Interaction Book Company.

Johnson, D.W., \& Johnson, R. (1989b). Leading the cooperative school. Edina, MN: Interaction Book Company.

Joyce, B., \& Weil, M., (1992). Models of teaching. Fourth Edition. Englewood Cliffs, NJ: Prentice-Hall.

Lobo, Y. B., \& Winsler, A. (2006). The effects of a creative dance and movement program on the social competence of head start preschoolers. Social Development. 15, 501-519.

McMillan, D.W., \& Chavis, D.M. (1986). Sense of community: A definition and theory. Journal of Community Psychology, 14, 6-23.

McNeill, W.H. (1995). Marching Together in Time: Dance and Drill in Human History. Cambridge, MA: Harvard University Press.

Merrell, K. W. (2001) Assessment of children's social skills: recent developments, best practices, and new directions. Exceptionality, $9(1 \& 2), 3-18$.

Oakland, T. D., \& Jimerson, S. R. (2007). School psychology internationally: A retrospective view and influential conditions. In S. R. Jimerson, T. D. Oakland \& P. T. Farrell (Eds.). The handbook of international school psychology (pp. 453-462). Thousand Oaks, CA: Sage.

Pitsi, A., Smilios, H., Tokmakidis, SP, Serbezis, B., \& Goulimaris, D. (2008). Heart Rate and Oxygen Consumption of Middle Aged People during the Performance of Greek Traditional Dances. (in Greek). Inquiries in sport \& Physical Education, 6(3), 329-339.

Sarason,S.B. (1974). The psychological sense of community: Prospects for community psychology. San Francisco: Jossey-Bass.

Sharan, S., \& Shachar, C., (1988). Language and Learning in the cooperative classroom. Springer. New York.

Slavin, R.E. (1989). Research on cooperative Learning: Consensus and controversy. Educational Leadership 47(4), 52-54. 